\title{
TEOLOGI PEMBEBASAN MENURUT GUSTAVO GUTIERREZ DAN IMPLIKASINYA BAGI PERSOALAN KEMISKINAN
}

\section{Marthinus Ngabalin}

\begin{abstract}
The just and civilized humanitarian movement takes precedence in liberation theology. Because the foothold of this theology is a historical praxis grounded in the reality of society. Guttierrez provides theological fundamentals in the real reality of a subject that he pummeled, that is problem of proverty. It's realized that poverty is part of the struggle of every people, including in Papua. Therefore, the church must be present and contribute to poverty not only on material matters but also spiritual matters.
\end{abstract}

Keywoord: Teology, Liberation, Poverty

\begin{abstract}
Abstrak
Gerakan kemanusiaan yang adil dan beradab diutamakan dalam Teologi Pembebasan. Sebab tempat berpijak teologi ini adalah praksis historis berpijak pada kenyataan yang terjadi dalam masyarakat. Gutierrez memberikan pendasaran teologi pada realita yang nyata sebuah pokok yang digumulinya yaitu masalah kemiskinan. Disadari bahwa kemiskinan, menjadi bagian dari pokok pergumulan setiap masyarakat, termasuk di Papua. Oleh sebab itu, gereja mesti hadir dan turut memberikan kontribusi dalam hal kemiskinan bukan hanya pada persoalan material tetapi juga masalah spiritual.
\end{abstract}

Kata Kunci: Teologi, Pembebasan, Kemiskinan

\section{PENDAHULUAN}

Masalah kemiskinan dan dampak yang ditimbulkannya adalah juga pokok bahasan dalam ilmu teologi atau ilmu agama, apa pun agamanya dan bukan hanya menjadi perhatian dalam ilmu-ilmu sosial. Untuk itu, bagi para teolog, upaya penelitian dan pembahasan mengenai masalah kemiskinan adalah bagian dari tanggung jawab moral dan iman kepada masyarakat sekaligus kepada Tuhan yang memberikan hidup ini. ${ }^{1}$ 
Kemiskinan merupakan fenomena yang terjadi hampir di semua negara yang sedang berkembang seperti kemiskinan yang terjadi di Indonesia. Kemiskinan muncul karena ketidak-mampuan sebagian masyarakat untuk menyelenggarakan hidupnya sampai suatu taraf yang dianggap manusiawi. Kondisi ini menyebabkan menurunnya kualitas sumberdaya manusia, sehingga produktivitas dan pendapatan yang diperolehnya sangat rendah. Lingkaran kemiskinan terus terjadi, karena dengan penghasilan yang rendah tidak mampu mengakses sarana pendidikan, kesehatan dan nutrisi secara baik sehingga menyebabkan kualitas Sumber Daya Manusia (SDM) dari aspek intelektual dan fisik menjadi sangat rendah, berakibat produktivitas juga menjadi rendah. Selain itu, rendahnya kualitas SDM menyebabkan kelompok ini tersisih dari persaingan ekonomi, politik, sosial budaya maupun psikologi sehingga semakin tidak mampu mendapatkan kesempatan yang baik dalam sistem sosial ekonomi masyarakat. ${ }^{2}$

Teologi Pembebasan (Liberation Theology) muncul di tengah keprihatinan Gereja-Gereja di Amerika Latin terhadap kondisi real masyarakatnya yang merindukan kehidupan yang lebih baik. Salah satu penyebabnya adalah karena upaya-upaya tersebut belum menyentuh akar penyebab kemiskinan itu. Penyebabnya bukan sekedar dikarenakan faktor-faktor ekonomi, tetapi terkait juga dengan faktor struktur sosial yang ada, dimana kehidupan sosial ekonomi masyarakat dikuasai oleh golongan elit. Mereka ini berusaha mengawetkan keadaan yang ada karena sangat menguntungkan mereka. Mereka juga membina relasi dengan pimpinan Gereja dengan memberikan sumbangan-sumbangan besar, yang kemudian oleh Gereja diteruskan sebagai pelayanan karikatif kepada umat (rakyat) yang menderita. Tidak adanya perubahan dalam struktur sosial ini membuat masyarakat tetap hidup dalam kemiskinan.

Dalam kondisi inilah gereja-gereja di Amerika Latin menggumuli makna kehadirannya. Pertanyaan pokok yang dijawab adalah "bagaimana memberitakan Allah yang pengasih itu di tengah-tengah kehidupan orang-orang yang tertindas?" Sebagian besar rakyatnya hidup dalam kemiskinan. Mula-mula mereka dikuasai dan ditindas oleh tuan-tuan tanah pribumi dan kemudian oleh bangsa penjajah. Setelah kemerdekaan muncul golongan elit baru yang menguasai kehidupan sosial dan ekonomi. Pemerintah telah berupaya memperbaiki keadaan 
yang ada dengan mengembangkan pembangunan terutama di bidang ekonomi, namun semua upaya itu belum berhasil membebaskan rakyatnya dari belenggu kemiskinan dan keterbelakangan.

Gereja menyadari bahwa untuk memperbaiki kondisi masyarakatnya, tidaklah cukup kalau hanya dengan berkhotbah, melayani sakramen, atau dengan memberikan bantuan-bantuan sekadarnya. Pertama-tama, gereja harus ikut memperhatikan penderitaan rakyat, berpihak kepada mereka yang menderita, dan terlibat di dalam upaya-upaya untuk memberdayakan rakyat yang tidak berdaya ini (miskin, tertinggal dan tertindas). Beriman kepada Kristus, terkait dengan upaya mewujudkan makna nyata karya penyelamatan yang telah dikerjakanNya, untuk dirasakan dan dialami dalam kehidupan saat ini.

Tema "Pembebasan" juga relevan untuk konteks masyarakat kita yang mendambakan terwujudnya masyarakat adil, makmur, tentram dan damai. Masalah kemiskinan, keterbelakangan, keadilan sosial (khususnya pemerataan dalam menikmati hasil-hasil pembangunan), ditambah lagi dengan terpaan badai berbagai krisis yang melanda kehidupan bangsa ini, telah menjadi keprihatinan bersama. Tuntutan agar pemerintah segera mengadakan reformasi di berbagai bidang (politik, ekonomi dan hukum), tujuannya antara lain untuk membebaskan masyarakat dari beban keprihatinan ini. Dalam konteks inilah Gereja berteologi. Sambil beriman dan beribadah kepada Tuhan, juga berpartisipasi dalam upayaupaya perbaikan dan peningkatan taraf hidup masyarakat.

\section{LATAR BELAKANG HIDUP GUSTAVO GUTIERREZ}

Gustavo Gutierrez Merino lahir pada tanggal 8 Juni 1928 di Monserat, sebuah kawasan miskin di Lima, ibu kota Peru. Ia berasal dari keluarga sederhana yang berdarah Mestizo, keturunan campuran Hispanic (Spanyol) dan Indian. Dalam keluarga yang memiliki tiga orang anak itu, Gutierrez adalah satu-satunya anak laki-laki, meskipun ada kesulitan-kesulitan ekonomi, ia tidak mengalami kekurangan cinta dari keluarganya. Bahkan dalam sebuah wawancara, Gutierrez berkata bahwa ia menerima begitu besar kasih sayang dari orang tua dan keluarganya.

Ketika berada di bangku sekolah menengah, Gutierrez diserang penyakit osteomiletis. Penyakit ini menyebabkan kepincangan permanen pada dirinya. 
Penyakit ini pulalah yang menuntun dia memilih jurusan farmasi pada Universitas San Marcos, Lima. Akan tetapi, kemudian ia memutuskan untuk masuk seminari dan belajar filsafat-teologi di Seminari Santiago de Chile. ${ }^{3}$

Pada tahun 1951-1955, ia melakukan tugas belajar pada Universitas Katolik Louvain, Belgia. Ia memperoleh gelar master dalam bidang filsafat dan psikologi dengan tesis Konflik Psikis dalam Freud. Di Louvain, ia bersahabat baik dengan Francois Houtart, yang kelak menjadi teolog sosial garda depan Gereja Katolik. Ia juga bersahabat baik dengan Camilo Torres, yang kelak menjadi pastor gerilyawan di Amerika Latin.

Pada tahun 1955-1959, ia melanjutkan kuliah teologi di Universitas Katolik Lyons, Prancis, dan memperoleh gelar master teologi dengan tesis Kebebasan Religius. Di Lyons, ia diperkenalkan dengan la nouvelle theologie, yakni upaya beberapa pemikir Katolik Prancis menghubungkan secara nyata iman dengan masalah-masalah abad ke-20, diantaranya Henri de Lubac, Jean Daniellou, Yves Congar. Mereka adalah teolog-teolog Barat yang cukup berpengaruh dalam pemikiran Gutierrez selain Karl Rahner dan G. von Rad. ${ }^{4}$

Gutierrez sempat pula belajar teologi di Universitas Katolik Gregoriana, Roma pada tahun 1959-1960. Di Roma pula ia ditahbiskan sebagai imam pada tanggal 6 Januari 1959. Setelah itu pada tahun 1960, ia kembali ke Amerika Latin dan mengajar di Universitas Katolik Lima, Peru. Namun, tugas utama yang dilakukan Gutierrez adalah menjadi pastor yang hidup dan berkarya diantara kaum miskin di Rimac, Lima. Di sini pulalah ia memperoleh landasan dan arah baru dalam pemikiran teologisnya.

Rimac adalah sebuah wilayah pemukiman kumuh di pinggiran kota metropolitan Lima. Seperti lazimnya dalam pembangunan di negara-negara berkembang, kehadiran sebuah kota metropolitan megah meninggalkan kantongkantong wilayah miskin. Rimac merupakan gambaran wilayah-wilayah yang tergusur oleh derap pembangunan. Rimac dihuni oleh banyak orang yang mesti berjuang keras untuk sekadar bisa hidup. Di Rimac inilah Gutierrez hidup dan bersatu dengan penderitaan dan harapan kaum miskin. Di sini pula ia menjadi juru bicara yang mengekspresikan perjuangan kaum miskin dalam bahasa teologis. ${ }^{5}$ 
Dalam keterlibatannya di tengah-tengah kaum miskin, Gutierrez merasakan bahwa perjalanan studi di Eropa selama ini tidak memberikan dasar kokoh baginya untuk memahami dan menghayati situasi Amerika Latin. Ia menemukan ketidak-cocokan antara teologi Barat yang dipelajari dengan kenyataan kongkret yang ada. Karena itu, ia mulai mempelajari dengan serius sejarah bangsanya sendiri. Ia membaca lagi Injil dan teologi dalam konteks Amerika Latin, yakni situasi kaum miskin dan tertindas.

Hal ini memperkenalkan dia dengan pemikir-pemikir besar Amerika Latin. Salah satu tokoh yang berpengaruh besar terhadap Gutierrez adalah Bartolome de Las Casas (1484-1566). Las Casas adalah imam Dominikan yang menjadi pembela orang-orang Indian Amerika terhadap penjajahan Spanyol. Gutierrez melihat kesamaan besar antara apa yang ditemukan oleh de Las Casas pada abad ke-16 dan kenyataan Amerika Latin pada abad ke-20 ini: kenyataan orang-orang mati sebelum waktunya (people died before their time). Penjajahan Spanyol mengakibatkan begitu banyak orang Indian mati secara prematur dan tidak adil. Karena itu, evangelisasi gereja di Amerika Latin menurut de las Casas bukan terutama menginisiasi orang kafir masuk dalam kebudayaan Kristiani Barat, tetapi melakukan advokasi terhadap kaum miskin yang tertindas. Orang-orang Indian harus diperlakukan sebagai orang miskin dalam arti injili dari pada orang-orang kafir. Maka menurut Gutierrez, pandangan terbesar yang diberikan de Las Casas adalah bahwa Kristus berbicara kepada kita dalam diri orang-orang Indian yang miskin. Hal ini pula yang relevan untuk zaman sekarang agar kita mengalami kehadiran potensial kaum miskin sebagai pewarta kabar gembira Kristus sendiri. ${ }^{6}$

Selain de la Casas, pemikir Amerika Latin yang memberikan banyak inspirasi kepada Gutierrez adalah Jose Carlos Mariategui (1895-1930). Ia adalah seorang pemikir Marxis dari Peru. Menurut Michal Candelaria, Mariategui memberikan tiga sumbangan penting bagi pemikiran Gutierrez, yakni; Pertama, penemuan sosialisme Peru yang asli dari perspektif kaum miskin; Kedua, perjuangan kelas sebagai suatu kunci penafsiran, yakni dalam situasi konflik sosial, posisi netral adalah tidak mungkin dan orang harus mengambil posisi kaum tertindas; Ketiga, kesatuan teori dan praksis. Praksis harus mengantar orang pada refleksi dan refleksi harus diverifikasi oleh praksis. ${ }^{7}$ 
Tokoh Peru lainnya yang berpengaruh pada Gutierrez adalah Jose Maria Arguedas (1911-969). Ia adalah seorang antropolog, penyair dan novelis. Arguedas sungguh menyadari situasi konflik sosial di Peru antara golongan kaya (Mestizo) dan golongan miskin (Campessino). Tak heran kalau hampir semua novelnya mengisahkan konflik sosial tersebut. Dan menurut Gutierrez, kejeniusan Arguedas terletak dalam pengenalannya yang cermat terhadap perjuangan dialektis antara golongan kaya dan miskin sebagai sebuah kenyataan inheren dalam negeri Peru. Hal yang mempertalikan mereka secara pribadi, yakni dalam keprihatinan dasar yang sama untuk memahami dan bersuara bagi kaum miskin. ${ }^{8}$

\section{KARYA-KARYA GUSTAVO GUTIERREZ}

Karya-karya Gustavo Gutierrez diawali pada tahun 1971, ketika ia menerbitkan karya monumentalnya $A$ Theology of Liberation (terjemahannya dalam bahasa Inggris, 1973). Sebuah buku yang menguraikan secara sistematis dan komprehensif refleksi teologis Gutierrez dalam konfrontasi dengan dunia kaum miskin di Amerika Latin yang ia hidupi selama ini. Buku ini secara lantang menyuarakan jeritan penderitaan kaum miskin yang tidak pernah dicatat dalam sejarah. Buku ini pula sekaligus mengungkapkan harapan kaum miskin terhadap kehadiran Allah yang membebaskan dalam sejarah. ${ }^{9}$

Dalam tahun-tahun selanjutnya, terbit beberapa buku lainnya dari Gutierrez yang bertolak dari keprihatinan dasar yang sama, yaitu bagaimana menyuarakan jeritan kaum miskin Amerika latin dalam bahasa teologis. Pada tahun 1979, terbit The Power of the Poor in History (edisi bahasa Inggris, 1983) yang berupa kumpulan esai mengenai visi Konferensi Para Uskup Amerika Latin di Medellin, Kolombia (1968), Konferensi Puebla (1979), kekhasan teologi pembebasan dalam perbandingan dengan teologi Barat. Pada tahun 1983, terbit We Drink from Our Own Well (edisi bahasa Inggris, 1984) yang berbicara tentang spiritual pembebasan. Pada tahun 1986, On Job: God Talk and the Suffering of innocent (edisi bahasa Inggris, 1987) yang merupakan tafsir kitab Ayub dalam konteks Amerika Latin. Pada tahun 1986, terbit The Truth Shall Make You Free (edisi bahasa Inggris, 1990) yang berisi rangkuman analisis sosial maupun pandangan teologisnya. Kemudian terbit The God of Life tahun 1990 
(edisi bahasa Inggris, 1992) yang berbicara tentang Allah dalam Kitab Suci dari perspektif Amerika Latin. Pada tahun 1992, terbit Las Casas: In Search of the Poor of Jesus Christ (edisi Bahasa Inggris, 1993), sebuah karya besar penelitian historis tokoh yang dianggap telah memelopori teologi pembebasan pada abad ke$16 .^{10}$

Peran sebagai artikulator kaum miskin tidak hanya Gutierrez melalui buku-buku teologi, tetapi juga dalam Konferensi-konferensi Para Uskup Amerika Latin (CELAM). Dalam Konferensi Medellin tahun 1968 yang membicarakan Gereja dalam situasi transformasi Amerika Latin, Gutierrez berperan aktif di dalamnya yang menghasilkan dokumen-dokumen yang berisi keprihatinan dasar terhadap kenyataan ketidakadilan sosial di Amerika Latin. Medellin kemudian dikenal sebagai tonggak sejarah Gereja Amerika Latin dalam menyatakan dirinya secara autentik sebagai yang memihak kaum miskin yang terjerat oleh mekanisme "kekerasan yang melembaga" (institusionalized violence).

Begitu pula dalam Konferensi Puebla tahun 1979, Gutierrez berperan aktif di belakang layar. Meskipun dalam Konferensi ini ia tidak diundang secara resmi oleh kelompok penyelenggara konferensi yang konservatif, ia tetap hadir secara tidak resmi oleh undangan uskup-uskup yang membutuhkan kehadirannya. Puebla kemudian menghasilkan dokumen yang menegaskan keprihatinan Medellin tentang pilihan untuk mendahulukan kaum miskin (the preferential option for the poor).

Pada tahun 1980-1986, Vatikan melalui Kongregasi untuk Ajaran Iman yang diketuai Kardinal Ratzinger, mengadakan penyelidikan terhadap teologi pembebasan termasuk teologi Gutierrez. Kongregasi ini kemudian menerbitkan dua dokumen berisi instruksi-instruksi tentang teologi pembebasan (6/8/984 dan 5/4/1986). Dalam dokumen I ada beberapa kritik keras pada teologi pembebasan seperti reduksi iman pada politik, yakni penggunaan ideologi Marxis. Bahwa pelbagai tuduhan itu tidak benar ditunjukan oleh pelbagai dukungan yang diperoleh Gutierrez dari banyak pihak baik secara pribadi maupun ilmiah. Gutierrez dianggap sebagai teolog Katolik yang paling ortodoks. Hal ini misalnya diperlihatkan oleh penganugerahan gelar doktor summa cum laude kepadanya oleh Universitas Katolik Nijmegen, Belanda (1979) dan dari Universitas Tubingen, Jerman (1985). 
Dukungan yang luas tampak jelas dalam simposium pada tahun 1988 di Maryknoll, New York untuk menghormati Gutierrez dalam rangka ulang tahunnya yang ke-60 dan publikasi edisi ulang tahun ke-15 karyanya yang masyhur, A Theology of Liberation. Pelbagai kalangan hadir entah secara langsung maupun lewat makalah seperti Kardinal P. A. Arns dari Brasil, Kardinal Stephen Kim dari Korea Selatan, Uskup Desmon Tutu dari Afrika Selatan, E. Schillebeeckx, F. Houtart, Harvey Cox, Jon Sobrino, L. Boff, E.S. Fiorenza, J.B. Metz, A. Pieris, E. Wiesel, dan lain-lain. ${ }^{11}$

Selain aktif dalam CELAM (Converencial Efiscopal Latino Americana), ${ }^{12}$ Gutierrez terlibat dalam banyak kegiatan gerejani yang lain. Ia adalah penasihat pelbagai kelompok pastoral dan refleksi teologis, anggota pendiri ONIS (Oficina Nacional de Investigacion), anggota editor majalah Concilium dan Paginas, Partisipan konferensi-konferensi EATWOT (Ecumenical Association of Third World Theologians), pembicara dalam Konferensi Lambeth Uskup-uskup Anglikan, Canterbury, Inggris pada tahun 1988. Ia juga mengajar di pelbagai tempat. Selain di Universitas Katolik Lima, Peru, ia pernah mengajar di Union Theological Seminary, New York; Pacific School of Religion, Berkeley, California; University of Michigan, Annarbar; Boston College, Boston; Maryknol School of Theology, New York; Mexican American Cultural Center, San Antonio, Texas; Cambridge University, Inggris, dan lain-lain.

Dengan pelbagai aktifitas yang kaya tersebut, banyak sebutan yang dapat dikenakan pada Gutierrez. Ia adalah teolog, profesor, dosen, pendidik, cendekiawan, aktivis, imam. Tetapi yang paling utama baginya adalah hidup sebagai pastor yang melayani kaum miskin. Baginya, menulis dan mengajar adalah bagian dari karya pastoral. Begitu pula teologi merupakan bantuan bagi pelayanan pastoral gereja. ${ }^{13}$

\section{KONSEP TEOLOGI PEMBEBASAN MENURUT GUSTAVO GUTIERREZ}

Dalam bagian ini kita akan melihat tiga hal dalam memahami secara integral arti pembebasan Kristiani dalam pandangan Gutierrez. Pertama, makna pembebasan Kristiani yang dikontraskan dengan perkembangan; Kedua, makna 
pembebasan Kristiani dalam kaitan dengan penyelamatan Allah; Ketiga, makna teologi pembebasan.

\section{a. Pembebasan dan Perkembangan}

Pembebasan (liberation) merupakan istilah kunci dalam teologi Gutierrez, Karena itu kita perlu memahami secara tepat bagaimana ia menggunakan istilah ini. Pertama-tama ia mengkontraskannya dengan istilah perkembangan (development). ${ }^{14}$ Gutierrez menolak penggunaan istilah perkembangan, sebab istilah ini tidak menyajikan gambaran yang tepat dan menyeluruh tentang realitas Amerika Latin sekaligus membatasi problem teologis yang muncul dari realitas sosial itu. Sebaliknya, baginya istilah pembebasan menyajikan gambaran yang utuh dan menyeluruh (sosial, personal dan teologis) tentang realitas Amerika Latin.

Pertama, pembebasan memperlihatkan realitas konfliktual dalam proses ekonomi, politik, sosio-budaya Amerika Latin yang membagi masyarakat dalam kelas kaya dan kelas miskin. Sekaligus menunjukan aspirasi dan perjuangan kelas sosial tertindas (miskin) untuk keluar dari lilitan penindasan itu (dimensi sosial). Kedua, pembebasan menunjukan pada martabat pribadi manusia yang memiliki kebebasan dan tanggung jawab atas nasibnya. Karena itu perubahan sejati dari struktur sosial tak adil tercapai kalau dilaksanakan oleh pribadi yang bebas (dimensi peronal). Ketiga, istilah pembebasan memiliki dasar biblis yang fundamental, yakni karya pembebasan Allah bagi umat-Nya. Allah dalam Yesus Kristus bertindak membebaskan manusia dari dosa dengan segala akibatnya termasuk ketidakadilan sosial (kemiskinan). Maka, istilah pembebasan menunjuk pula pada rahmat, yakni anugerah pembebasan dari Allah kepada manusia. Dalam kerangka rahmat Allah inilah dapat dibangun perjuangan pembebasan manusia atas struktur sosial yang tidak adil (dimensi teologis). Singkatnya, pembebasan menunjuk pada perjuangan manusia dalam mewujudkan diri secara autentik dan dalam mengatasi struktur sosial yang menindas (represif) dan menghisap (eksploitatif) berpangkal pada rahmat pembebasan yang diberikan Allah. ${ }^{15}$

\section{b. Karya Penyelamatan Allah dalam Sejarah}


Istilah pembebasan berkaitan erat pula dengan istilah penyelamatan. Gutierrez menyatakan bahwa penyelamatan-persatuan manusia dengan Allah dan dengan seluruh manusia adalah sesuatu yang mencakup seluruh realitas manusia, mentransformasinya dan menuntunnya menuju kepenuhan dalam Kristus. Penyelamatan merangkum manusia seutuhnya dan seluruhnya dalam dimensi kemanusiaannya yang jasmani dan rohani, yang individual dan sosial, manusia dan kosmos, kesementaraan dan kekekalan. Penyelamatan adalah realitas yang sekaligus intrahistoris dan transhistoris.

Pembebasan terutama digunakan Gutierrez untuk menunjukan dinamika penyelamatan yang terjadi dalam sejarah manusia atau menekankan realitas intrahistoris penyelamatan. Pembebasan adalah suatu proses yang meliputi semua dan yang tidak membiarkan satu pun dimensi hidup manusia tidak disentuh, karena ketika semua itu dikatakan dan dikerjakan, hal-hal itu mengekspresikan karya Allah dalam sejarah. Proses pembebasan mencakup transformasi struktur yang tidak adil (pembebasan sosial), perwujudan manusia baru (pembebasan personal), pembebasan dari dosa/teologis (pembebasan total dalam Kristus).

Maka, pembebasan adalah proses transformasi sejarah manusia dalam rangka dinamika perwujudan Kerajaan Allah. Namun Gutierrez mengingatkan, meskipun pembebasan historis adalah pertumbuhan Kerajaan Allah dan suatu peristiwa penyelamatan, tetapi ia bukanlah kedatangan Kerajaan Allah, bukan mengungkapkan seluruh penyelamatan. Pembebasan adalah realisasi historis Kerajaan yang selalu terbuka pada pemenuhan di masa depan, yakni kedatangan Kerajaan yang merupakan anugerah Allah. ${ }^{16}$

\section{c. Teologi Pembebasan}

Berdasarkan relasi penyelamatan dan pembebasan tersebut, Gutierrez mendefinisikan teologi pembebasan sebagai suatu teologi penyelamatan dalam kondisi-kondisi konkret, historis, dan politis dalam dunia dewasa ini. Situasi historis ini ditandai oleh kemiskinan akibat ketidakadilan sosial (situasi Amerika Latin). Karena itu ia kerap pula menyebut teologi pembebasan sebagai teologi kaum miskin, teologi yang memiliki teman bicara (interlocutor) kaum miskin dan mengartikulasikan perjuangan dan harapan mereka. Teologi ini berbeda dengan 
teologi progresif/dominan di Barat yang memiliki teman bicara dan menjawab masalah kaum borjuis. ${ }^{17}$

Aspek mendasar dalam teologi pembebasan adalah fokusnya pada 'praxis'. Refleksi kritis pada praksis secara umum dilihat sebagai cara di mana teologi pembebasan dilukiskan secara metodologis. Praksis sama sekali tidak menggantikan pengetahuan rasional dan penyataan. Prioritasnya pada praksis yang bersifat pembebasan atau tindakan historis. ${ }^{18}$ Dalam pandangan Gutierrez, deskripsi tentang teologi sebagai "critical reflection on praxis", memperlihatkan kecenderungan yang lebih luas dan konstruktif. Teologi harus menjadi refleksi kritis manusia terhadap dirinya pada basis prinsipnya. Dengan pendekatan ini teologi akan menjadi diskursus yang serius, sadar tentang dirinya, sadar akan elemen-elemen konseptualnya. Refleksi teologi dengan demikian, menjadi suatu aspek kritis tentang masyarakat dan gereja sejauh kritik itu diletakkan di bawah Firman Allah.

Sehingga baginya, kemiskinan bukan secara material, ketiadaan kebutuhan bahan pokok ekonomi, tetapi juga kemiskinan spiritual, yaitu suatu sikap inferior yang tak tersentuh oleh kebutuhan dunia. Kemiskinan material sebagai suatu 'scandalous condition' dan kemiskinan spiritual sebagai suatu sikap keterbukaan kepada Allah, menghasilkan komitmen, solidaritas dan protes. Sadar akan situasi dan realitas kemiskinan, ia menyatakan bahwa, untuk melayani orang miskin kita harus bergeser kepada political action. Orang-orang miskin dalam konteks teologi pembebasan mencakup dimensinya yang luas. Mereka yang didominasi, dieksploitasi, didiskriminasi, dimarjinalisasi. Orang-orang miskin merupakan suatu universe, ketika aspek sosial ekonomi menjadi dasar. Bagi Gutierrez, kemiskinan berarti kematian, ketiadaan makanan, perumahan, kesehatan, pendidikan, eksploitasi pekerja, pengangguran, kehilangan respek kepada martabat manusia, pembatasan kebebasan personal, politik dan agama. ${ }^{19}$

Kepedulian Gutierrez, untuk orang miskin mendorongnya untuk bekerja dengan orang miskin. Dalam perjumpaannya dengan orang miskin ia menemukan tiga hal penting, yaitu: ${ }^{20}$

1. Kemiskinan adalah destruktif, sesuatu yang merusak, dan bukan secara kebetulan atau dapat dibenarkan pada basis Alkitab 'Seperti orang-orang miskin selalu ada padaMu' 
2. Kemiskinan bukan sesuatu kecelakaan, tetapi sesuatu yang struktural. Orang-orang miskin adalah hasil dari sistem. Mereka hidup pada bagian pinggiran dari dunia sosial dan kultural, ditindas, dieksploitasi, kemanusiaan mereka direndahkan. Mereka miskin bukan karena persoalan perubahan, tetapi karena dosa struktur. Karenanya perlu untuk mengkonstruksi suatu tatanan sosial baru.

3. Orang miskin adalah kelas sosial; orang miskin termasuk pada level kebudayaan dan tidak dihormati sebagai the others, kelas sosial yang dieksploitasi. Memilih orang miskin berarti memilih satu kelas sosial dan melawan kelas sosial yang lain, sadar akan perjuangan kelas dan mengidentifikasi diri dengan kepedulian dan perjuangan mereka.

\section{REFLEKSI TEOLOGI SOSIAL TERHADAP KEMISKINAN}

Dalam sebuah wawancara, Gutierrez menegaskan bahwa di mana masih ada orang miskin, teologi pembebasan tetaplah relevan. Teologi pembebasan Gutierrez bukanlah satu-satunya teologi pembebasan yang berkembang di Amerika Latin. Munculnya teologi pembebasan tidaklah secara tiba-tiba namun didahului dengan berbagai proses yang bertahap. ${ }^{21}$

Teologi Gutierrez, adalah teologi pengalaman. Dikatakan demikian karena teologi ini didasarkan pada refleksinya atas pengalamannya dan juga pengalaman orang miskin. Pengalaman tersebut adalah hasil perjalanan panjang nan berliku sebagai anggota komunitas umat beriman di dalam satu sistem yang menindas. Teologi pengalaman dikembangkan oleh Gutierrez karena ia tidak melihat lagi bahwa teologi merupakan sebuah perangkat kebenaran yang tidak berubah, melainkan sebuah refleksi atas pengalaman penghayatan Injil komunitas Kristiani. Refleksi ini bersifat eksperiensial namun diungkap dengan pendekatan rasional yang meyakinkan.

Gutierrez, sendiri sungguh-sungguh merenungkan dua simbol utama iman Kristiani yaitu Yesus dan Komunitas umat beriman yang dinamakan Gereja. Pribadi serta pesan Yesus dan gereja tidak dapat dilepaskan satu sama lain. Keduanya menyatu dalam mewartakan Kerajaan Allah. Seperti Yesus sendiri, umat Kristiani menginkarnasikan diri sebagai sebuah simbol pemberian hidup 
dalam sejarah. Gereja mewartakan kemungkinan keselamatan meskipun ada dosa dan penindasan.

Sehubungan dengan defenisi teologi, maka menurut John Macquarrie, bahwa teologi adalah:

"Suatu studi yang melalui partisipasi dan refleksi dalam suatu komunitas iman, yang berusaha pula untuk menyatakan inti iman itu dalam bahasa yang sejelas dan sepadan mungkin". ${ }^{22}$

Rumusan di atas sebagai pintu masuk dalam menjelaskan teologi sosial yaitu suatu teologi yang berupaya untuk merumuskan penghayatan iman Kristiani pada konteks ruang dan waktu tertentu atau sesuai dengan perubahan realitas sosial yang ada dalam masyarakat, sehingga teologi benar-benar menjadi teologi sosial apabila memiliki keterlibatan langsung dengan masalah-masalah sosial dan memanusiakan manusia. Teologi sosial juga merupakan teologi yang kontekstual, sebab teologi yang dilakukan memperhatikan dan mempertemukan secara dialektis, kreatif serta eksistensial antara teks dan konteks dalam rangka menghadirkan keadilan, kesetaraan dan pembebasan pada masa sekarang dan akan datang seperti masalah kemiskinan yang dihadapi oleh masyarakat Indonesia dewasa ini.

Teologi sosial memiliki ciri-ciri sosial atau kontekstual, yang membicarakan masalah dimensi realitas sosial yang terjadi dalam masyarakat. Sebagai keprihatinan utama membicarakan tentang keadilan, kesetaraan, dan perdamaian. Dimana dalam masyarakat sering terjadi ketimpangan-ketimpangan sosial, keadaan yang demikian memerlukan kepekaan teologi dalam menanggapi pergumulan yang ada secara jelas dan tajam. Bukan hanya memberikan suatu jawaban sebagai kesadaran palsu atau bahkan memberikan pengharapan utopia yang ilusi. Tetapi sungguh-sungguh menghadirkan keadilan, kesetaraan, dan perdamaian yang benar-benar nyata dalam suatu relalitas sosial kehidupan masyarakat dan mengubah realitas menuju kepada yang diharapkan. Dasar pengharapan kita adalah pemberitaan Yesus tentang Kerajaan Allah, yang pemerintahanNya senantiasa menghadirkan kasih, perdamaian, keselamatan, keadilan dan keutuhan.

Pendekatan yang sangat cocok bagi teologi sosial kita adalah memakai analisa sosial teori kritis. Selama ini teologi kita mengalami suatu teologi yang 
pejoratif. Dikatakan pejoratif karena teologi yang dari sifat ideologisnya menciptakan kesadaran palsu. Keadaan yang demikian dikritik oleh Karl Marx, mengapa kehidupan orang Kristen tidak memberikan inspirasi bagi setiap orang dalam melakukan perubahan. Selama ini agama menjadi candu dalam masyarakat bahkan agama pun mendorong orang untuk menganiaya sesamanya guna mengagungkan perasaan dan pendapat mereka sendiri atas perasaan dan pendapat orang lain ${ }^{23}$. Ideologi semacam ini mengalami suatu kesadaran palsu sebab menganggap mereka adalah pemilik tunggal kebenaran. Bahkan di tengah arus perubahan dan modernisasi, banyak sekali orang mengalami rasa keterasingan, kehilangan pegangan, dan ketidak-berdayaan. Karena itu teologi kita perlu dan harus mampu peka dan tanggap terhadap realitas sosial yang ada. Seperti masalah kemiskinan yang dihadapi oleh masyarakat Indonesia, banyak dari penduduk Indonesia yang belum menikmati pendidikan, kesehatan dan kesejahteraan dan hidup layak sebagai manusia. Kemiskinan yang dialami oleh masyarakat Indonesia bisa jadi karena kemiskinan struktural di mana masyarakat sengaja ditindas oleh kekuasaan atau institusi yang menindas masyarakat kecil sehingga tidak mampu untuk bersaing. Sedangkan kemiskinan alamiah dapat terjadi karena keterbatasan dan rendahnya sumber daya manusia dan alam yang tersedia, sehingga masyarakat tidak bisa berbuat banyak.

Menurut Baum, teologi secara konstan berada dalam dialog dengan teori kritis disebut sebagai “Teologi Kritis” (Critical Theology), adalah

“Aplikasi/penerapan kritis dari berbagai teori tentang alienasi terhadap pemahaman iman dari Gereja Kristen. Belajar dari reori sosial yang menjelaskan tentang bagaimana manusia terasing (teralienasi) juga berbagai kritik agamawi, para teolog memahami kecenderungan yang ideologis dan pathogenis dalam tradisi agamawi mereka dan dalam masyarakat". ${ }^{24}$

Sebagai awal masuknya adalah fakta hadirnya Kerajaan Allah yang terwujud dalam kehadiran Yesus Kristus mencakup baik pengertian personal maupun sosial. Di mana berita yang dibawa oleh Yesus dialamatkan bagi semua orang baik secara pribadi maupun secara persekutuan.

Teologi Sosial yang merupakan teologi kontekstual haruslah berorientasi pada identitas dan modernitas. Karena teologi yang tidak memperhitungkan 
budaya akan merupakan teologi yang tidak berakar, teologi yang terasing dari alam pemikiran dan sistem nilai yang ada. Tetapi bila teologi hanya memperhatikan pada budaya saja maka teologi pun kehilangan fungsi kritisnya, maka teologi pun tidak berfungsi sebagai teologi. Selain itu, sikap kritis terhadap sistem nilai dan budaya tradisional merupakan sebagai aspirasi masyarakat terhadap modernitas. Berarti aspirasi tidak dapat diabaikan, bila benar-benar menciptakan teologi yang kontekstual. Sebaliknya bila teologi hanya memperhatikan aspek sosial, politik, dan ekonomi, apalagi didasarkan pada konsep Barat, maka akan menjadi teologi yang asing. Atau teologi yang memberikan ideologi kesadaran palsu dan membodohkan serta memiskinkan manusia.

Dengan demikian, teologi akan kontekstual apabila teologi tidak berada dalam sebuah 'menara gading' yang sukar untuk menyentuh realitas sosial masyarakat bahkan melakukan perubahan. Teologi akan kontekstual apabila menghadirkan Kerajaan Allah di bumi sekarang ini dan juga yang akan datang. Teologi akan kontekstual apabila juga tidak membodoh-bodohi, melainkan memanusiakan manusia. Teologi akan dikatakan kontekstual apabila juga membebaskan manusia dari kemiskinan, ketidakadilan dan ketidaksetaraan.

Teologis sosial dimulai dengan kenyataan sosial atau situasi yang dialami bersama. Untuk menangkap situasi yang dialami bersama, diperlukan analisis yang dibutuhkan dari berbagai ilmu yang terdiri dari; analisis sosial, analisis historis, analisis kultural dan analisis personal. $^{25}$ Dengan demikian, bagi Nuhamara, tujuan dari analisa sosial adalah untuk memahami berbagai sistem dominasi dalam masyarakat serta ideologi yang mendasarinya, untuk kemudian melakukan kritik ideologi. Inilah fungsi kenabian gereja dalam mengembangkan teologinya. Kritik ini bisa berarti kritik sosial tetapi sekaligus juga kritik agamawi, sebab ideologi yang peyoratif bisa berasal dari berbagai sistem kemasyarakatan tetapi juga dari institusi agamawi yakni teologinya. Jadi dengan berdialog dengan teori kritis, gereja diharapkan dapat melakukan kritik sosial dan agamawi sekaligus. Lebih khusus lagi gereja dimampukan melakukan kritik ideologi bahkan kritik diri sendiri yakni kritik terhadap teologi yang distorsif, yang menyebabkan manusia teralienasi bukan saja dari diri sendiri dan sesama 
tetapi juga dari alam ciptaan Tuhan oleh nafsu menguasai dan mendominasi baik sesama maupun alam ciptaan Tuhan ${ }^{26}$.

Baum dalam buku, Religion and Alienation menjelaskan tentang apa itu teologi kritis? Dan bagaimana tugas dan tanggung jawab gereja dalam menyingkapi realita yang terjadi. Menurut Baum: Dengan demikian, tugas dan tanggung jawab gereja adalah bukan saja mengajarkan tentang iman umatnya, namun juga melihat konsekwensi struktural dari praktek agama, untuk mengevaluasinya dipandang dari sudut pengajaran gereja berdasarkan norma, untuk memungkinkan gereja mengatur kembali kehadiran sosialnya sehingga konsekwensi sosial nya mendekati pernyataan imannya. Karena sehubungan dengan Injil Kristen tidaklah hanya pengajaran gereja dan mengambil keuntungan sejarah manusia. Teologi kritis memungkinkan gereja untuk mengasumsikan tanggung jawab mengenai agama untuk kenyataan sosialnya. Dalam pengertian ini, kemudian Teologi kritis adalah "cerminan atas praksis". ${ }^{27}$

\section{PENUTUP}

Tulisan ini sifatnya teoritis, namun konsep yang ditawarkan oleh Gustavo Gutierrez tetap relevan dalam sejarah pergumulan hidup, dimana di dalamnya Gutierrez kemudian mendefinisikan teologi sebagai "critical reflection on praxis in the light of God's word." Ada tiga aspek yang terkandung dalam teologi pembebasan Amerika Latin.

1. Pembebasan dari belenggu penindasan ekonomi, sosial dan politik atau alienasi kultural serta kemiskinan dan ketidakadilan.

2. Pembebasan dari kekerasan yang melembaga.

3. Pembebasan dari dosa yang memungkinkan manusia masuk dalam persekutuan dengan Tuhan dan semua manusia.

Ketiga unsur tersebut adalah refleksi kritis atas iman; iman yang dihayati dalam konteks sejarah konkret Amerika Latin, iman yang dalam penghayatannya dibimbing oleh Wahyu Tuhan baik dalam bentuk verbal maupun tanda sejarah. 
Endnotes :

${ }^{1}$ Ricardo F Nanuru, Gereja di Jalan Keadilan, dalam Yusak B Setyawan, dkk (Peny), Perdamaian dan Keadilan Dalam Konteks Indonesia Yang Multikultural dan Beragam Tradisi Iman, Jakarta: Pokja Teologi Kontekstual Mission 21 + (Jakarta: BPK Gunung Mulia, 2017), hlm. 410

${ }^{2}$ Gunawan Sumodiningrat, Pemberdayaan Masyarakat dan JPS. (Jakarta ; PT Gramedia Pustaka Utama, 1999), hlm. 14

3 James B Nickoloff, Gustavo Gutierrez: Essential Writings, London: SCM Press, 1996, h. 18; Martin Chen Pr. Teologi Gustavo Gutierrez refleksi dari praksis kaum miskin, (Yogyakarta: Kanisius 2002), hlm. 26-29

${ }^{4}$ Ibid., James B. Nockoloff

${ }^{5}$ Ibid., James B. Nickoloff

${ }^{6}$ Ibid., James B. Nickoloff

${ }^{7}$ John Chr. Ruhulessin, Etika Publik: Menggali dari Tradisi Pela di Maluku, (Salatiga: Program Pascasarjana Program Studi Sosiologi Agama UKSW Salatiga, 2005), hlm. 68-69

${ }^{8}$ Ibid., John Chr. Ruhulessin

${ }^{9}$ http://filsafat.kompasiana.com/2011/11/28/memabaca-teologi-pembebasan-di-tengah kapitalisme-global-416540.html diakses tgl. 20 Mei 2017.

10 Ibid., http://filsafat.kompasiana.com/2011/11/28/memabaca-teologi-pembebasan-di-tengahkapitalisme-global-416540.html

${ }^{11}$ http://justisianto.com/?p=57 diakses tgl 21 Mei 2017

${ }^{12}$ Wiliam Chang, Berteologi Pembebasan, (Jakarta: Obor, 2005), hlm. 91

${ }^{13}$ F Wahono Nitiprawira, Teologi Pembebasan : Sejarah, metode, praksis dan isinya, (Bandung: Pustaka Bandung, 2001), hlm. 35

${ }^{14}$ Martin Chen, ibid, hlm. 80

${ }^{15}$ Ibid, hlm. 82

${ }^{16}$ Ibid, hlm. 83-84

${ }^{17}$ Ibid, hlm. 83

${ }^{18}$ Gustavo Gutierrez, A Theology of Liberation, (New York: Marykonoll, Orbis Books, 1973), hlm. 97

${ }^{19}$ Ibid., Gustavo Gutierrez, A Theology... hlm. xxi

${ }^{20}$ Gutierrez dalam John Chr. Ruhulessin, ibid, hlm. 70

21 A Nugroho Widiyono, Masyarakat, Yesus dan Komunitas Kristiani: Mengenal Pemikiran Teologi Pembebasan Gustavo Gutierrez Bersama Curt Cadorrete, Fenomena: Jurnal Mahasiswa Teologi Universitas Sanata Dharma, Edisi XIII/ Mei 2004: Sebuah Diskursus: Teologi, Politik dan Pembebasan, (Yogyakarta: Sanata Dharma, 2004), hlm. 23

22 John A. Titaley, Menuju Teologi Agama-agama yang kontekstual, dalam rangka Pidato pengukuhan Jabatan Fungsional Akademik Guru Besar Ilmu Teologi di Universitas Kristen Satya Wacana, (Salatiga: UKSW, 29 November 2001), hlm. 4.

${ }^{23}$ Bryan S. Turner, Agama dan Teori Sosial, (Yogyakarta ; Ircisod, 2003), hlm. 118.

${ }^{24}$ Gregory Baum, Religion and Alienation: Theological Reading of Sociology, (New York : Paulist, 1975), h. 196. Band. Daniel Nuhamara, Kritik, Utopia dan Praksis Pembebasan: Unsurunsur dalam Berteologi Sosial Transformatif dalam Kritis: Jurnal Studi Pembangunan Interdisiplin, Vol. XVI, No. 3, Desember 2004, hlm. 6

${ }^{25}$ Untuk uraian selengkapnya tentang analisis tersebut, baca: J. B. Banawiratma, et.al, Aspekaspek Teologi Sosial, Yogyakarta: Kanisius, 1990, h. 11-12; J. B. Banawiratma, et.al, Berteologi Sosial Lintas Ilmu: Kemiskinan Sebagai Tantangan Hidup Beriman, (Yogyakarta: Kanisius, 1993), hlm. 23-30.

26 Daniel Nuhamara, Kritik, Utopia dan Praksis Pembebasan: Unsur-unsur dalam Berteologi Sosial Transformatif dalam Kritis: Jurnal Studi Pembangunan Interdisiplin, Vol. XVI, No. 3, Desember 2004, hlm. 333.

${ }^{27}$ Ibid, Baum, hlm. 194 -195. 


\section{DAFTAR PUSTAKA}

Baum Gregory, 1975. Religion and Alienation : Theological Reading of Sociology, New York : Paulist

Banawiratma J. B, 1990, et.al, Aspek-aspek Teologi Sosial, Yogyakarta: Kanisius 1993, Berteologi Sosial Lintas Ilmu: Kemiskinan Sebagai Tantangan Hidup Beriman, Yogyakarta

Chen Martin Pr, 2002, Teologi Gustavo Gutierrez Refleksi dari Praksis Kaum Miskin, Yogyakarta: Kanisius

Chang Wiliam, 2005, Berteologi Pembebasan, Jakarta: Obor

Gunawan Sumodiningrat, 1999, Pemberdayaan Masyarakat dan JPS, Jakarta ; PT Gramedia Pustaka Utama

Gutierrez Gustavo, 1973, A Theology of Liberation, New York: Marykonoll, Orbis Books

Nanuru Ricardo F, 2017, Gereja di Jalan Keadilan, dalam Yusak B Setyawan, dkk [Peny], Perdamaian dan Keadilan Dalam Konteks Indonesia Yang Multikultural dan Beragam Tradisi Iman, Jakarta: Pokja Teologi Kontekstual Mission 21 +, Jakarta: BPK Gunung Mulia,

Nickoloff James B, 1996, Gustavo Gutierrez: Essential Writings, London: SCM Press

Nitiprawira F Wahono, 2001, Teologi Pembebasan : Sejarah, metode, praksis dan isinya, Bandung: Pustaka Bandung

Nuhamara Daniel, 2004, Kritik, Utopia dan Praksis Pembebasan: Unsur-unsur dalam Berteologi Sosial Transformatif dalam Kritis: Jurnal Studi Pembangunan Interdisiplin, Vol. XVI, No. 3, Desember 2004

Ruhulessin John Chr, 2005, Etika Publik: Menggali dari Tradisi Pela di Maluku, Salatiga: Program Pascasarjana Program Studi Sosiologi Agama UKSW Salatiga,

Titaley John A, 2001, Menuju Teologi Agama-agama yang kontekstual, dalam rangka Pidato pengukuhan Jabatan Fungsional Akademik Guru Besar Ilmu Teologi di Universitas Kristen Satya Wacana, Salatiga: Universitas Satya Wacana

Turner Bryan S, 2003, Agama dan Teori Sosial, Yogyakarta ; Ircisod 
Widiyono A Nugroho, 2004, Masyarakat, Yesus dan Komunitas Kristiani: Mengenal Pemikiran Teologi Pembebasan Gustavo Gutierrez Bersama Curt Cadorrete, Fenomena: Jurnal Mahasiswa Teologi Universitas Sanata Dharma, Edisi XIII/ Mei 2004: Sebuah Diskursus: Teologi, Politik dan Pembebasan, Yogyakarta: FTW-Universitas Sanata Dharma

\section{Situs Internet:}

http://filsafat.kompasiana.com/2011/11/28/memabaca-teologi-pembebasan-ditengah kapitalisme-global-416540.html diakses tgl. 20 Mei 2017.

http://justisianto.com/?p=57 diakses tgl 21 Mei 2017 